\title{
Effects of Salinity on Growth Performance and Blood Parameters of Butter Catfish, Ompok bimaculatus
}

\author{
Md. Asaduzzaman ${ }^{1}$ (D), Mohammad Amzad Hossain ${ }^{1}$ (D), Sohel Mian ${ }^{1}$ (i), Mohammed Mahbub lqbal ${ }^{1}$ (i)
}

Cite this article as: Asaduzzaman, M., Hossain, M.A., Mian, S., \& lqbal, M.M. (2022). Effects of salinity on growth performance and blood parameters of Butter Catfish, Ompok bimaculatus. Aquatic Sciences and Engineering, 37(2), 58-63.

ORCID IDs of the author: M.A. 0000-0002-7003-8974; M.A.H. 0000-0001-9219-3628; S.M. 0000-0001-5514-566X; M.M.I. 0000-0001-5720-4029

'Department of Fish Biology and Genetics, Faculty of Fisheries, Sylhet Agricultural University, Bangladesh

Submitted:

24.09.2021

Revision Requested: 10.12.2021

Last Revision Received: 17.12.2021

Accepted:

17.12.2021

Online Published:

25.01.2022

Correspondence:

Mohammad Amzad Hossain

E-mail:

mamzad.fbg@sau.ac.bd

\begin{abstract}
The study was conducted in laboratory conditions to evaluate the effects of salinity on growth, survival, and blood chemistry of butter catfish, Ompok bimaculatus fingerlings. The fry, initially sized as $7.01 \mathrm{~cm}$ length and $1.69 \mathrm{~g}$ weight, were assigned in four different salinity treatments i.e., 0 ppt $\left(T_{c}\right), 2$ ppt $\left(T_{1}\right), 4$ ppt $\left(T_{2}\right)$ and 8 ppt $\left(T_{3}\right)$ with three replications, with 21 fry in each replication as well. Fish were fed commercial catfish diets with $43 \%$ protein and $8 \%$ lipid at $5 \%$ body weight three times a day for 90 days. The control $\left(T_{C}\right)$ treatment showed the significantly highest growth performance among treatments, $(p<0.05)$. The $T_{3}$ treatment group showed a lethal parameter and all fish died within 72 hours of exposure to it. The survival rate was recorded as $90.47 \%$ for $T_{c^{\prime}}, 71.43 \%$ for $T_{1}$ and $47.61 \%$ for $T_{2}$ treatment. The mean weight and length gain $6.17 \mathrm{~g}$ and $4.93 \mathrm{~cm}$ observed in $T_{1}$ followed by $4.59 \mathrm{~g}$ and $3.06 \mathrm{~cm}$ in $T_{2}$ treatment. The specific growth rate (SGR) (\%) mean weight gain, length gain, average daily weight gain, average daily length gain and percentage length gain were (\%) found to be significantly higher in Tc in comparison to those in the salinity treated groups $(p<0.05)$. Significantly higher hemoglobin and WBC were observed in $T_{c}$ among treatments and had the lowest value recorded in $T_{1}$ and $T_{2}$. There were no significant changes between RBC counts among treatments.
\end{abstract}

Keywords: Salinity, growth performance, blood parameters, Ompok bimaculatus

\section{INTRODUCTION}

Being an aquatic animal, fishes largely depend on water quality for their physiological performance (Paul et al., 2019). The alarming rate of global warming leads to extreme exchanges in water temperature which directly or indirectly affect the aquatic resources drastically (Baum et al., 2005; Burel et al., 1996). This effect has driven the increase of saline water intrusion to freshwater and many freshwater fish are being affected (Kang'ombe \& Brown, 2008). Any changes in the optimal dilutions of salinity impose minor imbalance on the homeostasis of fish, which might be manifested by a set of physiological responses factors (Enayati et al., 2013). However, inadequate research has been done to define the salinity originated stress and growth performance in butter catfish.

Freshwater aquaculture has witnessed the broadening adoption of various endemic catfish into the culture due to a lucrative commercial return (Debnath et al., 2016). Commercial freshwater aquaculture has expanded rapidly in the past two decades by putting various indigenous catfish into the culture as they have promising growth, high profitability, and better consumer acceptance (Jayasankar, 2018). There are a number of catfish that are known to have numerous potential for freshwater aquaculture, among them butter catfish, $O$. bimaculatus, which is an indigenous common silurid fish of southeast Asian countries (Dhar et al., 2019; 
Mishra et al., 2018) and has gained importance due to its premium nutritional value, taste, less intermuscular spines, and high market price (Hossen et al., 2021; Chowdhury et al., 2020; Jabed et al., 2020). However, in recent times, this species is declining in nature driven by the loss of its wild habitat, indiscriminate use of pesticide and pollutants, hampering of breeding activities, and over exploitation of mature fish without consideration of the sex (Hossain et al., 2017; Malakar et al., 2012; Rawat, 2018). Therefore, it has been categorized as a "threatened" group since 2015 (IUCN Bangladesh, 2015). So, it is extremely important to save the fish from extinction through the use of a suitable cultural practice. Although, several tactics of successful induced breeding for this fish has been established (Banik \& Malla, 2015; Purkayastha et al., 2012; Rawat, 2018), it has not received much interest in commercial farming as there is a low larval survival rate which has created a shortage in t seed supply. It is an urgent necessity to work out the facts involving the low larval survival rate which is associated with their cannibalistic behavior, insufficient larval food supply, stocking density, environment borne stress, and rearing conditions.

Hemoglobin, RBC, WBC, cortisol, plasma glucose and hematocrit are considered essential indicators of the blood chemistry used to indicate the healthiness of fish (Dowidar et al., 2018; Soltan et al., 2016; Souza \& Bonilla-Rodriguez, 2007). Therefore, salinity and dietary food can be used as functional nutrients to ameliorate the hematological parameters as well as to improve overall physiological condition in fish. This research was conducted to evaluate the salinity that affects fish growth and survival. With increasing salinity, fish fall into stress which is related to the physiology of the body and ultimately affects its function as well as blood parameters. For these reasons, its growth and survival decline. This research was planned to study the salinity, growth, survival, and blood parameters which are related to one another.

\section{MATERIALS AND METHODS}

\section{Designing the experiments}

The fingerlings of $O$. bimaculatus were collected from a private fish hatchery and acclimatized for 14 days in an aquarium before commencing the trial. Homogeneous sized, healthy fingerlings were selected for this experiment. A total of 252 fish, comprising an initial mean body weight of $1.69 \mathrm{~g}$, were randomly distributed to 12 prepared glass aquariums accommodating 21 fish per aquarium (Table 1). Fish were fed $5 \%$ of their total body weight three times a day in the morning, afternoon, and night. The water was partially supplemented to compensate for evaporation loss, and fecal matter and other debris were removed regularly.

Table 1. Layout of the experiment.

\begin{tabular}{lccc} 
Treatment & $\begin{array}{c}\text { \% Feed fed of } \\
\text { body weight }\end{array}$ & Replication & $\begin{array}{c}\text { No. of } \\
\text { fingerling } \\
\text { released }\end{array}$ \\
\hline $\mathrm{T}_{c}$ (0ppt) & 5 & $\mathrm{R}_{1}, \mathrm{R}_{2}, \mathrm{R}_{3}$ & 21 \\
$\mathrm{~T}_{1}$ (2ppt) & 5 & $\mathrm{R}_{1}, \mathrm{R}_{2}, \mathrm{R}_{3}$ & 21 \\
$\mathrm{~T}_{2}$ (4ppt) & 5 & $\mathrm{R}_{1}, \mathrm{R}_{2}, \mathrm{R}_{3}$ & 21 \\
$\mathrm{~T}_{3}$ (8ppt) & 5 & $\mathrm{R}_{1}, \mathrm{R}_{2}, \mathrm{R}_{3}$ & 21
\end{tabular}

Water quality influences such as temperature, dissolved oxygen, $\mathrm{NH}_{3}$ and $\mathrm{pH}$ were determined at the beginning of the experiment and measured twice per week during the feeding trial.

A 90-day trial with different salinity treatment (Table 1) was allocated for fingerling of $O$. bimaculatus reared by using commercial pabda fish feed. The nutritional composition of the diet consisted of protein $43 \%$, carbohydrate $20 \%$, ash $12 \%$, lipid $8 \%$, fiber and minerals $3 \%$ each and moisture $11 \%$. The total dimensions of each aquarium was $0.762 \mathrm{~m} \times 0.381 \mathrm{~m} \times 0.381 \mathrm{~m}$ and each was cleaned properly with disinfectants and cleaning agents. Then, they were dried and filled to $2 / 3$ parts of its volume with clean tap water. A variable amount of $\mathrm{NaCl}$ was added to the water to adjust salinity to 2 ppt, 4 ppt and 8 ppt, and justified with a Refractometer as well. The control aquaria were maintained to 0 ppt i.e., without salt. Each aquarium was facilitated with an aerator with a filtration facility for proper oxygen supply.

\section{Sampling fish and water quality properties}

Sampling was performed fortnightly to determine the growth of fish. Weight was assessed with a digital electric balance (CAMRY digital, Model EK 3052, Bangladesh) and length was measured by a steel scale. Length and weight of all fish in each tank were measured month-wise during the study period. The value of temperature, $\mathrm{pH}$ and salinity were measured using SI digital DO meter, model 58, while $\mathrm{NH}_{3}$ was analyzed by using kit (Hanna Ammonia Test Kit HI-3824, Romania).

\section{Collection and analysis of blood chemistry}

At the end of the 90 day trial, 10 fish from each replicate were randomly selected for blood collection through caudal puncture with heparinized syringes to perform the complete blood count (CBC) test. Fish were starved for 24 hours prior to the final sampling. All the fish were sedated with eugenol (4-allylmethoxyphenol, Wako Pure Chemical Ind., Osaka, Japan), 50 mg L-1. Ten fish from each replicate were used for blood collection using $1 \mathrm{~mL}$ heparinized syringes (Jimi syringes and medical devices Ltd, Bangladesh) from the caudal vein. Following the collection of blood samples, CBC was performed in the central laboratory of Veterinary, Animal and Biomedical Sciences faculty, Sylhet Agricultural University, Sylhet, Bangladesh by using CBC analyzer.

\section{Growth analysis tools}

Major growth biometrics were calculated using the formulas described by (Htun-Han, 1978), (Pechsiri \& Yakupitiyage, 2005) and (Panase \& Mengumphan, 2015).

Weight gain of fish $(\%)=$ (Final weight -Initial weight / Initial weight) 100

The specific growth rate, $\operatorname{SGR}(\%)=\frac{\ln W 2-\ln W 1}{T 2-T 1} \times 100$, Where $\mathrm{W}_{1}=$ the initial body weight ( $\mathrm{gm}$ ) at a time, $W_{2}=$ the final body weight (gm) at a time, $T_{2}-T_{1}=$ Duration in days Average daily weight gain $=\frac{\text { Mean value of final weight-Mean value of initial weight }}{\text { Duration of experiment in days }}$

Average daily length gain $=\frac{\text { Mean value of final length-Mean value of initial length }}{\text { Duration of experiment in days }}$

The Fulton's condition factor value, $K=\left(W^{\star} 100\right) / L^{3}$ 


\section{Statistical analysis}

The result of fish growth performance was evaluated by using a one-way analysis of ANOVA and Duncan's multiple Range were analyzed using SPSS program version IBM 26.0.

\section{RESULTS AND DISCUSSION}

The readings for $\mathrm{pH}$, ammonia, dissolved oxygen, and temperature of the aquarium water were observed as presented in Table 2. The standard dissolved oxygen (DO) concentrations in the experimental tanks ranged from 5.49 to $5.68 \mathrm{mg} / \mathrm{L}$ during the entire experimental phase. Maximum $\mathrm{pH}$ was recorded 7.25 and lowest 7.01 The values of above parameters were found uniform for all treatment groups.

Water temperature is one of the parameters that directly affects fish growth and other biological activities (Burel et al., 1996; Rem et al., 2020). The water temperature above or below optimal thermal limits $\left(25-32^{\circ} \mathrm{C}\right)$ reduced the feed intake and growth performance in tropical fish culture (Cho et al., 2015; Fatma \& Ahmed, 2020). Low temperature drives the animals toward decreased metabolic rate, thus growth (Makori et al., 2017). Catfish reared in $31^{\circ} \mathrm{C}$ water temperature exhibited maximum growth compared to the ambient, $29^{\circ} \mathrm{C}$ and $33^{\circ} \mathrm{C}$ water temperature (Rem et al., 2020). The temperature observed in current work was found within the optimal range for animals' growth. The DO level >5 ppm is crucial to sustain fish production (Bhatnagar \& Devi, 2013). The optimal pH range for the suitable growth and development of butter catfish ranges between 6.0-8.0 (Riede, 2004), and levels during the experimental period were satisfactory. Fish were found dead at $\mathrm{pH}$ levels lower than 4 and higher than 11(Boyd \& Lichtkoppler, 1979). The maximum limit of ammonia for aquatic organisms was between 0.01-0.02 mg/L (Bhatnagar \& Singh, 2010; Santhosh, 2017). From the above information it is evident that the indicated water quality parameters in the present study were suitable for the butter catfish culture.

The highest mean weight gain was $10.62 \pm 0.56 \mathrm{~g}$ as observed in the $T_{C}$ group compared to $T_{1}$ and $T_{2}$ (Table 3 ). The $T_{3}$ treatment group's environment was lethal, and fish died within 72 hours after release into the aquarium. Again, the lowest weight gains of $4.59 \pm 59 \mathrm{~g}$ were recorded in the T2 treatment group. In comparison to the control group, a significant rise in weight gain $(p<0.05)$ was observed in $T_{c}$ and $T_{1}$. Significant increases in percentage weight gain (PWG) follows the same trend as well $(p<0.05)$. Specific growth rate was highest in $T_{c}$ as $2.29 \pm 0.29$, no significant differences were observed between $T_{1}$ and $T_{2}$. Lowest specific growth rate was found for $T_{1}$ treatment 1.48 \pm 0.24 , $(p<0.05)$ (table 3). The highest mean length gain was observed in $T_{c}$ was $6 \pm 0.46$ $\mathrm{cm}$, which is significantly higher among treatments, $(p<0.05$; Table 3). Among the treatments, $T_{2}$ showed the significantly lowest length gain in contrast to the $T_{c}$ and $T_{1},(p<0.05)$. The percentage of length gain follows the same trends. The PLG (\%) 44.00 99.69 and 69.6 \pm 7.25 were observed in $T_{2}$ and $T_{1}$ treatment groups, respectively. Among the treatments, no significance differences were found between $T_{1}$ and $T_{2}$ groups, whereas significant increases were observed in $T_{c}(p<0.05)$.

The growth performance revealed that the $T_{c}$ and $T_{1}$ treatment groups demonstrated better growth performance than that of

Table 2. Mean value of water quality parameters.

\begin{tabular}{lcccc}
\hline Parameters & Tc (0ppt) & T1 (2ppt) & T2 (4ppt) & T3 (8ppt) \\
\hline Temperature $\left({ }^{\circ} \mathrm{C}\right)$ & $29.3 \pm 1.56^{\mathrm{a}}$ & $29.6 \pm 1.42^{\mathrm{a}}$ & $28.9 \pm 1.39^{\mathrm{a}}$ & $29.11 \pm 1.52^{\mathrm{a}}$ \\
$\mathrm{pH}$ & $7.13 \pm 0.41^{\mathrm{a}}$ & $7.19 \pm 0.38^{\mathrm{a}}$ & $7.01 \pm 0.59^{\mathrm{a}}$ & $7.25 \pm 0.45^{\mathrm{a}}$ \\
$\mathrm{NH}_{3}$ (mg/l) & $0.028 \pm 0.09 \mathrm{a}$ & $0.018 \pm 0.08^{\mathrm{a}}$ & $0.011 \pm 0.09^{\mathrm{a}}$ & $0.021 \pm 0.09^{\mathrm{a}}$ \\
Dissolved Oxygen (mg/l) & $5.65 \pm 0.011^{\mathrm{a}}$ & $5.55 \pm 0.018^{\mathrm{a}}$ & $5.49 \pm 0.016^{\mathrm{a}}$ & $5.68 \pm 0.06^{\mathrm{a}}$
\end{tabular}

Table 3. Growth parameters of butter catfish of 90 days treatments.

\begin{tabular}{lccc}
\hline Parameters & Tc (0 ppt.) & T1 (2 ppt.) & T2 (4 ppt.) \\
\hline Mean Initial Weight (g) & $1.59 \pm 0.38^{\mathrm{a}}$ & $1.78 \pm 0.32^{\mathrm{a}}$ & $1.69 \pm 0.35^{\mathrm{a}}$ \\
Mean Final Weight (g) & $12.20 \pm 0.53^{\mathrm{a}}$ & $7.95 \pm 0.30^{\mathrm{b}}$ & $6.28 \pm 0.47^{\mathrm{c}}$ \\
Mean Weight Gain & $10.62 \pm 0.56^{\mathrm{a}}$ & $6.17 \pm 0.41^{\mathrm{b}}$ & $4.59 \pm 0.59^{\mathrm{c}}$ \\
\% Weight Gain & $709.42 \pm 193.95^{\mathrm{a}}$ & $360.38 \pm 87.50^{\mathrm{b}}$ & $286.32 \pm 83.23^{\mathrm{b}}$ \\
SGR \% & $2.29 \pm 0.26^{\mathrm{a}}$ & $1.44 \pm 0.2^{\mathrm{b}}$ & $1.48 \pm 0.24^{\mathrm{b}}$ \\
Mean Initial Length & $6.89 \pm 0.5^{\mathrm{a}}$ & $7.11 \pm 0.34^{\mathrm{a}}$ & $6.99 \pm 0.42^{\mathrm{a}}$ \\
Mean Final Length & $12.9 \pm 0.5^{\mathrm{a}}$ & $12.04 \pm 0.36^{\mathrm{b}}$ & $8.24 \pm 0.46^{\mathrm{c}}$ \\
Mean Length Gain & $6 \pm 0.46^{\mathrm{a}}$ & $4.93 \pm 0.37^{\mathrm{b}}$ & $3.06 \pm 0.58^{\mathrm{c}}$ \\
\% Length Gain & $150.11 \pm 11.5^{\mathrm{a}}$ & $69.6 \pm 7.25^{\mathrm{b}}$ & $44.00 \pm 9.69^{\mathrm{c}}$ \\
ADWG (g) & $0.12 \pm 00^{\mathrm{a}}$ & $0.07 \pm 00^{\mathrm{b}}$ & $0.05 \pm 00^{\mathrm{c}}$ \\
ADLG (cm) & $0.07 \pm 00^{\mathrm{a}}$ & $0.05 \pm 00^{\mathrm{b}}$ & $0.03 \pm 00^{\mathrm{c}}$ \\
Survival rate & $90.47 \pm 7.12^{\mathrm{a}}$ & $71.43 \pm 9.2^{\mathrm{b}}$ & $47.61 \pm 10.08^{\mathrm{c}}$ \\
\hline
\end{tabular}

Here, $S G R=$ Specific growth rate, $A D W G=$ Average daily weight gain, $A D L G=$ Average daily length gain. *Values are means $\pm S D$ of triplicate groups. Within a row, means with the same letters are not significantly different $(p>0.05)$. *Means in the column with different superscripts are significantly different $(P<0.05)$ 
the $T_{2}$ treatment. On the other hand, the $T_{2}$ treatment showed the lowest growth performance compared to the control group. A negative association between the increasing salinity and survival rate of seabream fish has already been documented by (Tandler et al., 1995). The study noted that as the nurturing salinity decreased from 40 to 25 ppt, the survival increased from 5.3 to $18.6 \%$. As high salinity increases, the fish metabolic rate falls into a stress condition, so the fish started growing more slowly (Dubey et al., 2016; Sakthivel et al., 2013). An extreme increase in salinity level might be lethal for fish (Tietze, 2016). The metabolic rate rises due to a gradual increase in the salinity range because freshwater fish can not tolerate saline water easily. The lethal salinity level for black bream was 60 ppt (Partridge \& Jenkins, 2002). Most fry of Ompok pabda were dead after 24 hour exposure to 2.5 ppt saline (Alam et al., 2020). Grass carp, Ctenopharyngodon has been reported to experience cardiac arrest associated with an ion imbalance following a long-term high concentration level of salinity (Enayati et al., 2013). A level of salinity above 11\%。 was found to be lethal for larvae (Gbulubo \& Erondu, 1998), while $>8$ ppt causes larval deformity and delayed hatching in African catfish (Clarias gariepinus) (Borode et al., 2002). Fish grew more on high food rations, but the growth and water content of the specimens declined with increasing salinity. The best growth performance observed in 0 ppt means freshwater was a freshwater fish. When saline water was added, the fish fell into stress and its growth ultimately declined. Overall, results show that without salt water the butter catfish grew very well depending on its food consumption rate.

The highest mean hemoglobin was found $3.45 \pm 0.13 \mathrm{~g} / \mathrm{dL}$ in $T_{c}$ followed by $3.11 \pm 0.08 \mathrm{~g} / \mathrm{dL}$ and $2.87 \pm 0.15 \mathrm{~g} / \mathrm{dL}$ in $T_{1}$ and $T_{2}$ treatments, respectively (figure $1 \mathrm{~A}$ ). There are significant differences found in $T_{c^{\prime}} T_{1}$ and $T_{2}(P<0.05)$, with significant increases of hemoglobin found in $T_{c}$ as compared to the $T_{1}$ and $T_{2}$. The highest number of WBC was found in T 53950 \pm 387.3 count/cumm which is significantly higher among treatments and followed by $T_{1}$ and $\mathrm{T}_{2} 53125 \pm 263.99$ count/cumm and $45275 \pm 403.11$ count/cumm, respectively (figure $1 \mathrm{~B}$ ). The maximum red blood cell (RBC) count was observed in $T_{c} 1.56 \pm 0.01 \mathrm{~m} / \mu \mathrm{l}$ which is followed by $1.49 \pm 0.03$ $\mathrm{m} / \mu \mathrm{l}$ and $1.10 \pm 0.07 \mathrm{~m} / \mu \mathrm{l}$ in $T_{1}$ and $T_{2}$, respectively (figure $1 \mathrm{~A}$ ). Significant decreases of RBC were observed in $T_{1}$ and $T_{2}$.

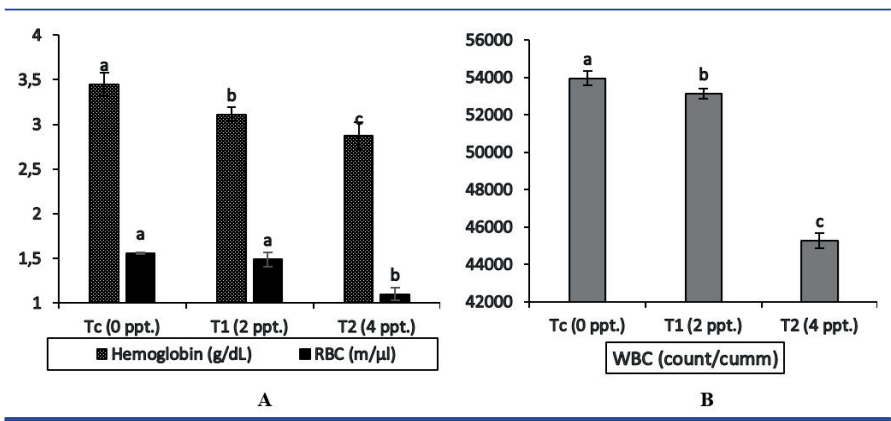

Figure 1. $(a, b)$ The blood parameters of Butter catfish at different treatments ( ${ }^{\mathrm{WBC}}=$ White blood Cell, $\mathrm{RBC}=$ Red Blood Cell *Values are means $\pm \mathrm{SD}$ of triplicate groups. Different superscripts are significantly different at $\mathrm{p}<0.05$ ).
A blood parameter reading is important in determining fish stressors and health factors (Hasan et al., 2021; Javed et al., 2016; Pandey, 1977). Fish growth observed in $T$ treatment was greater than other treatment groups. As the fish of $\mathrm{T}_{\mathrm{c}}$ treatment showed maximum growth performance, their blood parameters were also more satisfactory than any other treatment investigated in the present experiment. There were significant differences among treatments at $\mathrm{p}<0.05, \mathrm{~T}_{\mathrm{c}}$ showed increased WBC in comparison to $T_{1}$ and $T_{2}$ showed decreased $W B C$ in contrast to the control group. From this point, the count of WBC decreases with the increase of salinities. Hasan, (2016) experimented with Cyprinus carpio, and found a higher level of WBC at up to 10 ppt, but at 15 ppt it was drastically decreased. A drastic increase in the salinity level was found to negatively affect the hematological parameters in Cyprinus carpio (Mubarik et al., 2019; Salati et al., 2011). However, Tra catfish (Pangasianodon hypophthalmus) were able to acclimate to the salinity changes by modifying their $\mathrm{RBC}$ and $\mathrm{Hb}$ concentrations (Phuc et al., 2017). The $\mathrm{T}_{\mathrm{c}}$ treatments fish showed maximum growth performance and satisfactory WBC count. There is a correlation between the hemoglobin quantity and RBC count (Souza \& Bonilla-Rodriguez, 2007).

\section{CONCLUSION}

The results of the current experiment clarified that salinity has a negative effect on growth as decreased performance was observed in all weight/length parameters (mean, final, \%) with the increase in salinity. In the above findings, it can be concluded that the water without salinity is most suitable for the growth performance, survival, and blood parameters of butter catfish. Further experiments should be designed to find a way to maintain the water salinity in aquaculture for maximizing the growth performance of fish.

Conflict of Interest: The authors declare that there are no conflicts of interest.

Ethical Approval: The design of this study was approved with regional, institutional, and national animal ethics clearance through the documentation from Sylhet Agricultural University Research System (SAURES), Bangladesh.

Author Contributions: This manuscript covers the MS thesis works of the first author, he performed laboratory works and prepared reports. The second authors were responsible for instructing in laboratory assays and preparing and writing manuscripts for publication. The main concept and methodology were generated and academically supervised by the third and fourth author.

\section{REFERENCES}

Alam, M. R., Sharmin, S., Islam, S. M. M., Alam, M. A., Ehiguese, F. O., Pattadar, S. N., \& Shahjahan, M. (2020). Salinity intrusion affects early development of freshwater aquaculture species pabda, Ompok pabda. Aquaculture Reports, 18, 100476. [CrossRef]

Banik, S., \& Malla, S. (2015). Survival and growth rate of larval Ompok pabda (Hamilton-Buchanan, 1822) of Tripura, India: related to efficient feed. Proceedings of the Zoological Society, 68(2), 164-171. [CrossRef]

Baum, D., Laughton, R., Armstrong, J. D., \& Metcalfe, N. B. (2005). The effect of temperature on growth and early maturation in a wild population of Atlantic salmon parr. Journal of Fish Biology, 67(5), 1370-1380. [CrossRef] 
Bhatnagar, A., \& Devi, P. (2013). Water quality guidelines for the management of pond fish culture. International Journal of Environmental Sciences, 3(6), 1980-2009.

Bhatnagar, A., \& Singh, G. (2010). Culture fisheries in village ponds: a multi-location study in Haryana, India. Agriculture and Biology Journal of North America. [CrossRef]

Borode, A. O., Balogun, A. M., \& Omoyeni, B. A. (2002). Effect of salinity on embryonic development, hatchability, and growth of african catfish, Clarias gariepinus, eggs and larvae. Journal of Applied Aquaculture, 12(4), 89-93. [CrossRef]

Boyd, C. E., \& Lichtkoppler, F. (1979). Water Quality Management in pond fish culture Research and Development Series. International Center for Aquaculture, 22(22), 1-30.

Burel, C., Person-Le Ruyet, J., Gaumet, F., Le Roux, A., Sévère, A., \& Boeuf, G. (1996). Effects of temperature on growth and metabolism in juvenile turbot. Journal of Fish Biology, 49(4), 678-692. [CrossRef]

Cho, H. C., Kim, J. E., Kim, H. B., \& Baek, H. J. (2015). Effects of water temperature change on the hematological responses and plasma cortisol levels in growing of red spotted grouper, Epinephelus akaara. Development \& Reproduction, 19(1), 19-24. [CrossRef]

Chowdhury, G., Hossain, M. S., Dey, T., Akhtar, S., Jinia, M. A., Das, B., Islam, M. J., \& Iqbal, M. M. (2020). Effects of dietary probiotics on the growth, blood chemistry and stress response of pabda catfish (Ompok pabda) juveniles. AACL Bioflux, 13(3), 1595-1605.

Debnath, C., Dube, K., Saharan, N., Tiwari, V. K., Datta, M., Sahoo, L., Yadav, G. S., \& Das, P. (2016). Growth and production of endangered Indian butter catfish, Ompok bimaculatus (Bloch) at different stocking densities in earthen ponds. Aquaculture Research, 47(10), 3265-3275. [CrossRef]

Dhar, R., Pethusamy, K., Singh, S., Mukherjee, I., Seethy, A., Sengupta, B., Srivastava, T., Sarkar, S., Mandal, V., Karmakar, M., Gupta, S., Ghosh, A., \& Karmakar, S. (2019). Draft genome of Ompok bimaculatus (Pabda fish). BMC Research Notes, 12(1), 825. [CrossRef]

Dowidar, M., Abd ElAzeem, S., Khater, A. M., Awad Somayah, M., \& Metwally, S. A. (2018). Improvement of growth performance, immunity and disease resistance in Nile tilapia, Oreochromis niloticus, by using dietary probiotics supplementation. Journal of Animal Science and Veterinary Medicine, 3(2), 35-46. [CrossRef]

Dubey, S. K., Trivedi, R. K., Chand, B. K., Mandal, B., \& Rout, S. K. (2016). The effect of salinity on survival and growth of the freshwater stenohaline fish spotted snakehead Channa punctata (Bloch, 1793). Zoology and Ecology, 26(4), 282-291. [CrossRef]

Enayati, A., Peyghan, R., Papahn, A. A., \& Khadjeh, G.-H. (2013). Study on effect of salinity level of water on electrocardiogram and some of blood serum minerals in grass carp, Ctenopharyngodon idella. Veterinary Research Forum: An International Quarterly Journal, 4(1), 49-53.

Fatma, S., \& Ahmed, I. (2020). Effect of water temperature on protein requirement of Heteropneustes fossilis (Bloch) fry as determined by nutrient deposition, hemato-biochemical parameters and stress resistance response. Fisheries and Aquatic Sciences, 23(1), 1. [CrossRef]

Gbulubo, A. J., \& Erondu, E. S. (1998). Salinity influence on the early stages of the African catfish. Aquaculture International, 6(5), 369-379. [CrossRef]

Hasan, A. A. H. (2016). Effect of water salinity on some blood parameters of common carp (Cyprinus carpio). International Journal of Applied Agricultural Sciences, 2(1), 17. [CrossRef]

Hasan, R., Hossain, M. A., Islam, R., \& lqbal, M. M. (2021). Does commercial probiotics improve the growth performance and hematological parameters of Nile tilapia, Oreochromis niloticus? 4(2), 160-168. [CrossRef]

Hossain, M. A., Akter, M., \& Iqbal, M. M. (2017). Diversity of Fish Fauna in Kusiara River (Fenchungonj Upazilla), Northeast Bangladesh. Journal of Aquaculture in the Tropics, 32(1), 1-13.
Hossen, M. A., Hossain, M. A., Hasan, A. K. M. M., Das, B., Mian, S., \& labal, M. M. (2021). Observation of embryonic and larval developmental stages in endangered nona tengra (Mystus gulio) induced with S-GnRHa. Punjab University Journal of Zoology, 36(1), 91-99. [CrossRef]

Htun-Han, M. (1978). The reproductive biology of the dab Limanda limanda (L.) in the North Sea: seasonal changes in the ovary. Journal of Fish Biology, 13(3), 351-359. [CrossRef]

IUCN Bangladesh. (2015). Red List of Bangladesh Volume 1: Summary. In IUCN, International Union for Conservation of Nature, Bangladesh Country Office, Dhaka, Bangladesh.

Jabed, M. N., Hossain, M. A., Mian, S., Kabir, M. A., Mazumder, S. K., \& lqbal, M. M. (2020). Some aspects of reproduction in long whiskered catfish, Sperata aor (Hamilton 1822), from North-East Bangladesh. Aquaculture Studies, 21(2), 47-54. [CrossRef]

Javed, M., Ahmad, I., Ahmad, A., Usmani, N., \& Ahmad, M. (2016). Studies on the alterations in haematological indices, micronuclei induction and pathological marker enzyme activities in Channa punctatus (spotted snakehead) perciformes, channidae exposed to thermal power plant effluent. SpringerPlus, 5(1), 761. [CrossRef]

Jayasankar, P. (2018). Present status of freshwater aquaculture in India - A review. Indian Journal of Fisheries, 65(4), 157-165. [CrossRef]

Kang'ombe, J., \& Brown, J. A. (2008). Effect of salinity on growth, feed utilization, and survival of Tilapia rendalli under laboratory conditions. Journal of Applied Aquaculture, 20(4), 256-271. [CrossRef]

Makori, A. J., Abuom, P. O., Kapiyo, R., Anyona, D. N., \& Dida, G. O. (2017). Effects of water physico-chemical parameters on tilapia (Oreochromis niloticus) growth in earthen ponds in Teso North SubCounty, Busia County. Fisheries and Aquatic Sciences. [CrossRef]

Malakar, A. K., Lakra, W. S., Goswami, M., Singh, M., \& Mishra, R. M. (2012). Molecular identification of three Ompok species using mitochondrial COI gene. Mitochondrial DNA, 23(1), 20-24. [CrossRef]

Mishra, A., Sarkar, U. K., Kumar, R., Rawat, A., \& Verma, S. (2018). Gonadal maturity assessment of butter catfish (Ompok bimaculatus) from major rivers and tributaries of India during spawning season. Iranian Journal of Fisheries Sciences, 17(3), 458-470.

Mubarik, M. S., Asad, F., Zahoor, M. K., Abid, A., Ali, T., Yaqub, S., Ahmad, S., \& Qamer, S. (2019). Study on survival, growth, hematology, and body composition of Cyprinus carpio under different acute and chronic salinity regimes. Saudi Journal of Biological Sciences, 26(5), 999-1002. [CrossRef]

Panase, P., \& Mengumphan, K. (2015). Growth Performance, LengthWeight relationship and condition factor of backcross and reciprocal hybrid catfish reared in net cages. International Journal of Zoological Research, 11(2), 57-64. [CrossRef]

Pandey, B. N. (1977). Haematological studies in relation to environmental temperature and different periods of breeding cycle in an air breathing fish, Heteropneustes fossilis. Folia Haematologica (Leipzig, Germany: 1928), 104(1), 69-74.

Partridge, G. J., \& Jenkins, G. I. (2002). The effect of salinity on growth and survival of juvenile black bream (Acanthopagrus butcheri). Aquaculture, 210(1), 219-230. [CrossRef]

Paul, S., Mandal, A., Bhattacharjee, P., Chakraborty, S., Paul, R., \& Kumar Mukhopadhyay, B. (2019). Evaluation of water quality and toxicity after exposure of lead nitrate in freshwater fish, major source of water pollution. Egyptian Journal of Aquatic Research. [CrossRef]

Pechsiri, J., \& Yakupitiyage, A. (2005). A comparative study of growth and feed utilization efficiency of sex-reversed diploid and triploid Nile tilapia, Oreochromis niloticus L. Aquaculture Research, 36(1), 45-51. [CrossRef]

Phuc, N. T. H., Mather, P. B., \& Hurwood, D. A. (2017). Effects of sublethal salinity and temperature levels and their interaction on growth performance and hematological and hormonal levels in Tra catfish (Pangasianodon hypophthalmus). Aquaculture International, 25(3), 1057-1071. [CrossRef] 
Purkayastha, S., Sarma, S., Sarkar, U. K., Lakra, W. S., Gupta, S., \& Biswas, S. P. (2012). Captive breeding of endangered Ompok pabda with ovatide. Journal of Applied Aquaculture, 24(1), 42-48. [CrossRef]

Rawat, P. (2018). Ompok bimaculatus rearing potential with feed attractants used in aquaculture. International Journal of Pure \& Applied Bioscience, 6(6), 621-634. [CrossRef]

Rem, P., Chiayvareesajja, S., \& Suanyuk, N. (2020). Effects of temperature on growth performance and water quality in culture system of butter catfish (Ompok bimaculatus). Songklanakarin Journal of Science and Technology, 42(6), 1253-1258.

Riede, K. (2004). Global register of migratory species - from global to regional scales. final report of the R\&D-project 80805 081. Federal Agency for Nature Conservation, Bonn, Germany. June, 329.

Sakthivel, M., Deivasigamani, B., Alagappan, K. M., Kumaran, S., Balamurugan, S., \& Rajasekar, T. (2013). Seasonal changes in selected immune response of Mystus gulio and Mystus vittatus. Journal of Environmental Biology, 34(1), 37-42.

Salati, A. P., Baghbanzadeh, A., Soltani, M., Peyghan, R., \& Riazi, G. (2011). Effect of different levels of salinity on gill and kidney function in common carp Cyprinus carpio. Italian Journal of Zoology, 78(3), 298-303. [CrossRef]

Santhosh, S. B. (2017). Guidelines for water quality management for fish culture in Tripura. Publication No. 27. ICAR Research Complex for NEH Region, Tripura Centre, Lem.

Soltan, M. A., Fouad, I. M., \& Elfeky, A. (2016). Growth and feed utilization of Nile tilapia, Oreochromis niloticus fed diets containing probiotic. Global Veterinaria, 17(5), 442-450.

Souza, P. C. de, \& Bonilla-Rodriguez, G. O. (2007). Fish hemoglobins. Brazilian Journal of Medical and Biological Research, 40(6),769-778. [CrossRef]

Tandler, A., Anav, F. A., \& Choshniak, I. (1995). The effect of salinity on growth rate, survival and swim bladder inflation in gilthead seabream, Sparus aurata, larvae. Aquaculture, 135(4), 343-353. [CrossRef]

Tietze, S. M. (2016). Effects of salinity and pH change on the physiology of an estuarine fish species, Fundulus heteroclitus. Electronic Theses and Dissertations. 1518. 